3. Тасалов В.И. Теория дизайна и проектная культура / В.И. Тасалов // Техническая эстетика. - 1991. - № 7. - С.9.

Стаття надійшла до редакції 01.06.2012 р.

УДК 378.147:371.311.4

A. О. Кравцова,

асистент,

Криворізький педагогічний інститут ДВНЗ «Криворізький наиіональний університет»

\title{
ПІДГОТОВКА СТУДЕНТІВ ПЕДАГОГІЧНИХ ФАКУЛЬТЕТІВ ДО ОРГАНІЗАЦІЇ ГРУПОВОЇ ФОРМИ НАВЧАННЯ УЧНІВ
}

Кравиова А. О. Підготовка студентів педагогічних факультетів до організаиії групової форми навчання учнів.

У статті розглянуто питання підготовки студентів педагогічних факультетів до організації групової форми навчання учнів. Групова робота сприяє індивідуалізації процесу навчання, забезпечує використання знань у повному обсязі, підвищує відповідальність за кінщеві результати навчання.

Ключові слова: підготовка майбутніх учителів, групові форми навчання, педагогічні умови, колективне розв'язання, індивідуалізація прочесу навчання.

Кравиова А. А. Подготовка студентов педагогических факультетов к организачии групповой формы обучения учащихся.

В статье рассмотрен вопрос подготовки студентов педагогических факультетов $\kappa$ организации групповой формы обучения школьников. Групповая работа способствует индивидуализации процесса обучения, обеспечивает использование знаний в полном объёме, повышает ответственность за конечные результаты обучения.

Ключевые слова: подготовка будущих учителей, групповые формы обучения, педагогические условия, коллективное решение, индивидуализаџия процесса обучения.

Kravtsova A. Pedagogical faculty students training in schoolchildren organization of group forms learning.

The article deals with the problem concerning Pedagogical faculty students training in schoolchildren organization of group forms learning. Group activities stimulates individualization in the process of learning, guarantees the use of knowledge in full, increases one's responsibility for final results of learning material.

Key words: future teachers training, group forms of learning, pedagogical conditions, collective decision, individualization in the process of learning.

Постановка проблеми. Модернізація освіти потребує створення нової школи - психологічно й соціально необхідної для дитини, яка розвивається, для молоді з їі кризою самосвідомості і самовираження. Іншими словами, назріла необхідність розроблення нової моделі педагога, важливим компонентом якої $є$ професіоналізм учителя 3 інноваційним мисленням. Для цього недостатньо загальної ерудиції, інформаційної освіченості у системі соціальних знань. На першому місці має бути цілісна зрілість фахівця, уміння обирати пріоритети у своїй фаховій діяльності. Для вчителя початкової школи це завдання є на порядок вищим у порівнянні з іншими професіями.

На цьому акцентував увагу В. Сухомлинський, називаючи учительську професію людинознавством, наголошував, що від педагога залежить, чим стане серце дитини - «ніжною квіткою чи засушеною корою» [5]. 
Професійно-якісна підготовка студентів педагогічних факультетів вищих навчальних закладів нашої держави вимагає впровадження і відпрацювання інноваційних педагогічних ідей, перспективного досвіду, моделювання змін в організації навчально-виховного процесу, оскільки впровадження прогресивних педагогічних технологій потребує від майбутнього вчителя нової науково-методичної підготовки до здійснення інноваційної діяльності.

Сучасна професійна діяльність майбутнього вчителя початкових класів грунтується на його підготовці як високопрофесійного фахівця, який ознайомлений із сучасними світовими вимогами до навчально-виховного процесу школи першого рівня, підготовлений до організації навчальної діяльності молодших школярів як педагогічної взаємодії, що спрямована на розвиток кожної особистості, ii підготовку до розв'язання завдань життєтворчості.

Аналіз останніх досліджень i публікацій. Теоретичні основи професійної підготовки вчителя до педагогічної діяльності, сутність i специфіка педагогічних умінь, механізми їх формування у процесі професійно-педагогічної підготовки досліджували філософи, психологи, педагоги: О. Абдулліна, А. Алексюк, Л. Хомич, В. Бондар, В. Буряк, В. Галузинський, М. Євтух, В. Кан-Калик, М. Нікандров, В. Ковальов, Н. Ничкало, В.Семиченко, О. Савченко, Н. Кузьміна, Л. Кондрашова, В. Сластьонін, Б. Федоришин, Н. Кічук, О. Щербаков, Т. Шамова, Е. Карпова, В. Якунін, А. Богуш, В. Кузь, З. Курлянд, А. Линенко, О. Пєхота, Р. Хмелюк, О. Плахотник, Л. Хоружа, О. Пометун та інші.

Зважаючи на важливі результати досліджень стосовно застосування групової форми навчання учнів у практиці початкової школи, маємо зазначити, що грунтовних досліджень 3 предмету підготовки майбутніх вчителів початкової школи до організації групової форми навчання учнів не отримано [6].

Мета статті - розглянути питання підготовки студентів педагогічних факультетів до організації групової форми навчання учнів.

Виклад основного матеріалу. Актуалізація компетентнісного підходу в останні роки обумовлена цілою низкою чинників. Перехід від індустріального до постіндустріального суспільства диктує необхідність формування особистості, яка вміє жити в ситуації невизначеності, особистості, здатної до творчої самореалізації, до навчання впродовж життя, до прийняття конструктивних і компетентних дій у різноманітних видах життєдіяльності, людини відповідальної. Отже, учитель має бути готовим до реалізації завдань щодо модернізації освіти в контексті компетентнісного підходу.

Нині ми відчуваємо, що сучасному педагогу вже недостатньо для успішної професійної діяльності отримати вищу освіту й на цьому зупинитися, адже виникає потреба систематично поповнювати свої знання, вдосконалювати уміння, навички, отримувати знання з інших галузей тощо. Реалії сьогодення такі, що не лише молоді вчителі відчувають потребу в адаптації та психолого-педагогічній компенсації. Оновленні програми, 
підручники, технології поставили досвідченого вчителя в ситуацію адаптації до нових вимог і умов, він відчуває потребу в компенсації знань у тих аспектах професійної діяльності, які є для нього новими.

Готовність майбутнього вчителя початкової школи до організації групової форми навчання учнів грунтується на психологічній, педагогічній i предметній підготовці, що передбачає насамперед сформованість особистих якостей педагога.

Нові технології навчання передбачають використання самими викладачами й учнями різноманітних джерел інформації: це i традиційні джерела (наукова, методична, спеціалізована література, періодичні фахові видання тощо), і сучасні джерела, що 3'явилися завдяки розвитку комунікацій (Інтернет-ресурси, аудіозаписи, відеофільми, відеофайли, DVD- та CDдиски, текстові матеріали, слайди тощо).

Сучасні технології суттєво вплинули і на підходи до проведення занять. Останнім часом увагу педагогів привертають активні й інтерактивні форми і методи навчання, що грунтуються на діяльнісних та діалогічних формах пізнання, оскільки головними чинниками розвитку особистості $€$ взаємодія між людьми та предметно-практична діяльність [1, с.295].

Навчання як процес цілеспрямованої передачі і засвоєння визначеного досвіду можна здійснювати по-різному. Сутність такого здійснення визначається відповідною формою навчання. Категорія «форма навчання» належить до основних у дидактиці, однак у тлумаченні їі до цього часу немає повної єдності дослідників. Так, М. Скаткін, І. Лернер, В. Дяченко визначають загальні форми навчання (фронтальна, групова, індивідуальна) та конкретні (урок, семінар, екскурсія тощо). І. Бурлака, В. Вихрущ пропонують поряд із загальнородовим поняттям «форма навчання» видові «форма навчальної діяльності» [2, с.70].

Можна зробити висновок про те, що терміни «форма організації навчання» і «організаційна форма навчання» за своєю сутністю об'єднують навчальні заняття різної форми проведення й організацію співробітництва вчителя та учнів на цих заняттях.

Форма навчання як дидактична категорія означає зовнішній аспект організації навчального процесу, який пов'язаний із кількістю учнів, часом $i$ місцем навчання, а також порядком його здійснення.

Сутність форм організації навчання зводиться до такого: це зовнішне вираження узгодженої діяльності вчителя та учнів, що здійснюється у встановленому порядку та певному режимі.

У дидактиці відомі форми організації навчання за критерієм місця їх проведення поділяються на три групи:

- заняття, що проводяться в школі - урок, факультатив, семінар, практичні та лабораторні заняття, заняття в навчальних майстернях, співбесіда, консультація, екзамен тощо;

- заняття, що проводяться поза школою - екскурсії, олімпіади, конкурси, гуртки, студії, клуби, станції у позашкільних навчально-виховних закладах тощо; 
- заняття вдома - виконання домашніх завдань (самопідготовка).

На будь-якому навчальному занятті, яке стосується форм організації процесу навчання, учитель організовує навчальну діяльність учнів різного рівня залучення їх до спілкування між собою та вчителем.

Зовнішнім виявом такого спілкування, співпраці суб'єктів навчального процесу є форми організації навчальної діяльності учнів: індивідуальна, парна, групова, загальнокласна, фронтальна та їх різноманітні поєднання.

Отже, на уроці чи факультативі як формі організації процесу навчання використовуються різні форми організації навчальної діяльності учнів під безпосереднім чи опосередкованим керівництвом вчителя.

Що стосується поняття «форма навчання», то слід мати на увазі такі його ознаки, як рівень самостійності суб'єктів навчання при виконанні ними навчального плану та програм і використання контролю результатів [3, с.123].

Отже, різноманітні дидактичні поняття, що стосуються формальних ознак часу, місця, стилю спілкування, можна віднести до однієї з трьох педагогічних категорій: форма організації навчального процесу або навчання, форма організації навчальної діяльності та форма навчання або освіти.

Якщо в дидактиці загальноосвітньої школи є здобутки щодо розуміння основних дидактичних понять, методів, прийомів, засобів навчання, які сприяють підвищенню ефективності навчального процесу, зокрема уроку, то в дидактиці вищої школи тривалий час спостерігався консерватизм в удосконаленні організаційних форм навчальної діяльності, зашкарублість теоретико-методологічних засад. Це зумовлено частково й тим, що у вищій школі в багатьох випадках науково-педагогічною діяльністю займалися (та й займаються) фахівці без належної психолого-педагогічної підготовки. Серед частини викладачів вищої школи дотепер поширеною є така думка: щоб навчати студентів, достатньо добре знати свою дисципліну. У системі формування науково-педагогічних кадрів для вищої школи донині не приділяється належної уваги опануванню основ психології та педагогіки вищої школи [4, с.251].

Висновки. Аналіз наукових праць дозволяє стверджувати, що нині питання ефективної підготовки майбутніх учителів початкової школи до організації групової форми навчання учнів повною мірою не розв'язано.

Ефективне впровадження групової форми навчання учнів у навчальновиховний процес початкової школи вимагає від майбутніх учителів готовності до іiі організації.

Отже, виявлена суперечність між соціальним замовленням щодо впровадження в освітній процес початкової школи групової форми навчання, 3 одного боку, та недостатнім рівнем розробленості відповідного науковотеоретичного й дидактичного забезпечення в підготовці майбутніх учителів початкової школи - $з$ іншого, дозволяє констатувати актуальність окресленої вище проблеми.

\section{Лiтература}

1. Бухлова Н. В. Технологічні особливості підготовки вчителя до формування самоосвітньої компетентності учня у процесі післядипломної освіти / Н. В. Бухлова // 
Компетентнісно орієнтована освіта: досвід, проблеми, перспективи. - У 3-х томах. - Том 2. - Донецьк: Каштан, 2008. - С.295-302.

2. Освітні технології: [навч.-метод. посіб.] / О.М. Пєхота, А.З. Кіктенко, О.М. Любарська та ін.; за ред. О. М. Пєхоти. - К. : Видавництво А.С.К., 2003. - С.70.

3. Бондар В. І. Дидактика / В. І. Бондар. - К. : Либідь, 2005. - 264 с.

4. Кузьмінський А. І. Педагогіка вищої школи: [навч. посіб.] / А. І. Кузьмінський. - К. : Знання, 2005. - 486 с.

5. Сухомлинський В. О. Вибр. твори: В 5-ти томах В.О. Сухомлинський. - К., 1980. $-352 \mathrm{c}$.

6. Пометун О. I. Дискусія українських педагогів навколо питань запровадження компетентнісного підходу в українській освіті / О. І. Пометун // Компетентнісний підхід у сучасній освіті: світовий досвід та українські перспективи / за заг. ред. О. В. Овчарук. - К. : «K.I.C.», 2004. - 112 c.

Стаття надійшла до редакції 01.06.2012 р.

УДК 37(09)+1(09)

I. I. Гаврищак,

кандидат пед. наук, дочент,

Кременеиький обласний

гуманітарно-педагогічний

інститут ім. Тараса Шевченка

\section{ПЕДАГОГІЧНІ АСПЕКТИ В НАУКОВІЙ ДІЯЛЬНОСТІ ІММАНУЇЛА КАНТА}

Гаврищак I. I. Педагогічні аспекти в науковій діяльності Іммануїла Канта.

Статтю присвячено дослідженню педагогічної діяльності відомого німецького філософа I. Канта, особливу увагу приділено трактату "Про педагогіку», виокремлено конщептуальні засади педагогічних положень твору, здійснено аналіз викладащької діяльності німецького філософа.

Ключові слова: Іммануїл Кант, Кенігсберзький університет, педагогічна діяльність, педагогічна антропологія, виховання особистості.

Гаврищак И. И. Педагогические аспекты в научной деятельности Иммануила Канта.

Статья посвящена исследованию педагогической деятельности известного немецкого философа И. Канта, особенное внимание уделено трактату «O педагогике», выделены концептуальные идеи педагогических положений произведения, выполнен анализ преподавательской деятельности немецкого философа.

Ключевые слова: Иммануил Кант, Кенигсбергский университет, педагогическая деятельность, педагогическая антропология, воспитание личности.

Gavrischak I. Pedagogical aspects of the scientific activities of Immanuel Kant.

The article investigates pedagogical activity of a famous German philosopher I. Kant, special attention is paid to the treatise "On Pedagogy». The conceptual provisions of the pedagogical foundations of the work were singled out; the analysis of teaching of the German philosopher was made.

Key words: Immanuel Kant, the University of Knigsberg, pedagogical activity, pedagogical anthropology, education of the individual.

Іммануїл Кант (1724-1804) давно посідає одне 3 чільних місць в історії європейської та світової культури. Доробок філософа був і донині продовжує залишатися в центрі уваги вітчизняних і зарубіжних науковців: проблемі людини у творчості І. Канта присвячено дослідження В. Асмуса, Б. Бім-Бада, В. Бразаускі, М. Гайдегера, А. Гулиги, П. Гуревича, М. Деспленда, Ф. Каульбаха, П. Козловські, Г. Крутікової, М. Мамардашвілі, Г. Новічкової, Т. Ойзермана, 